
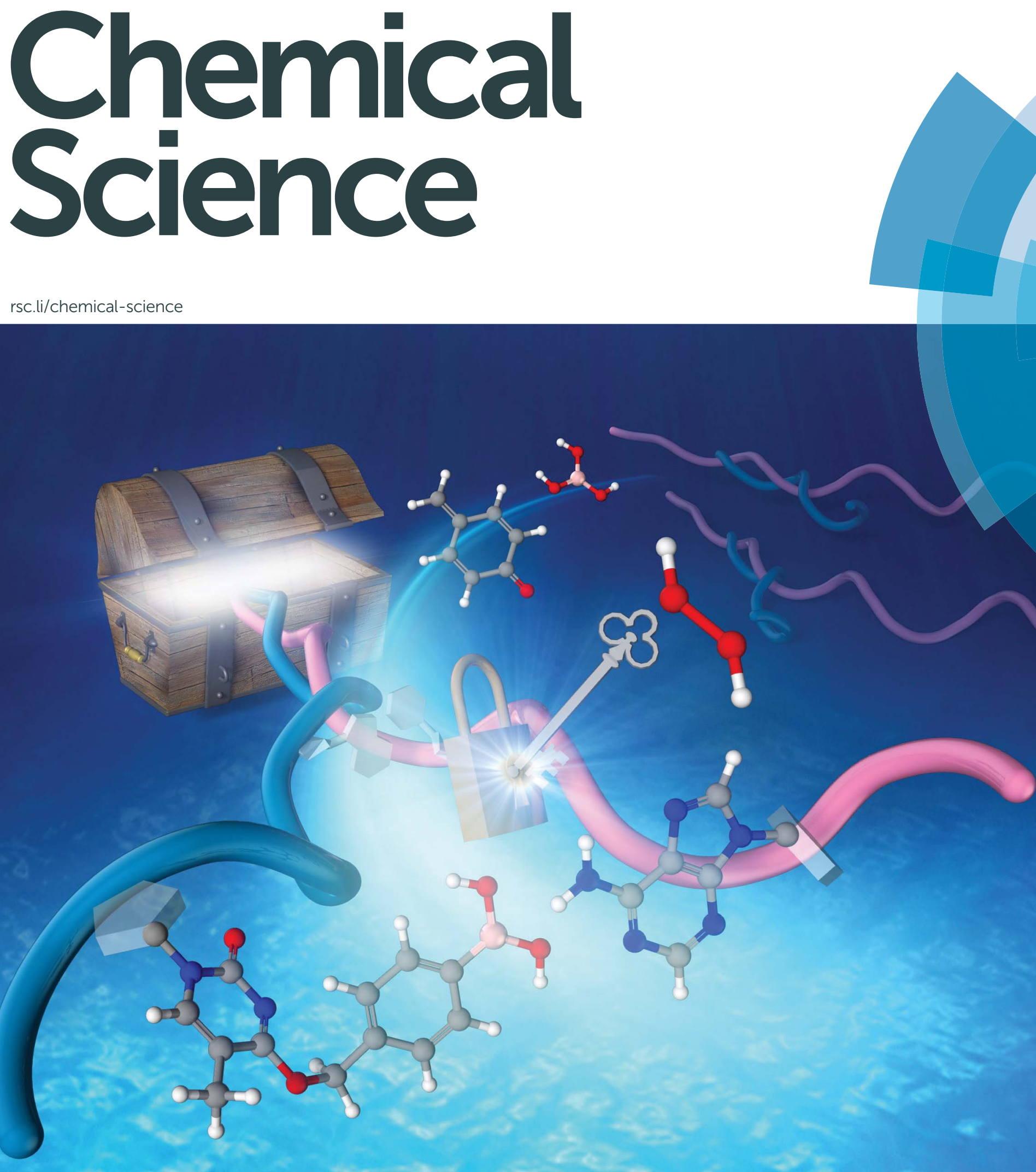

ISSN 2041-6539

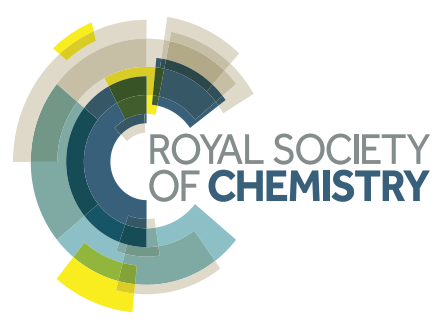


Check for updates

Cite this: Chem. Sci., 2018, 9, 1112

Received 5th October 2017

Accepted 21st November 2017

DOI: $10.1039 / \mathrm{c} 7 \mathrm{sc} 04318 \mathrm{j}$

rsc.li/chemical-science

\section{Hydrogen peroxide-triggered gene silencing in mammalian cells through boronated antisense oligonucleotides $\uparrow$}

\author{
Shohei Mori, ${ }^{a}$ Kunihiko Morihiro, ${ }^{* a b}$ Takumi Okuda, ${ }^{a}$ Yuuya Kasahara ${ }^{a b}$ \\ and Satoshi Obika (D) *ab
}

\begin{abstract}
Hydrogen peroxide $\left(\mathrm{H}_{2} \mathrm{O}_{2}\right)$ is a reactive oxygen species (ROS) involved in various diseases, including neurodegeneration, diabetes, and cancer. Here, we introduce a new approach to use $\mathrm{H}_{2} \mathrm{O}_{2}$ to modulate specific gene expression in mammalian cells. $\mathrm{H}_{2} \mathrm{O}_{2}$-responsive nucleoside analogues, in which the Watson-Crick faces of the nucleobases are caged by arylboronate moieties, were synthesized. One of these analogues, boronated thymidine $\left(\mathrm{dT}^{\mathrm{B}}\right)$, was incorporated into oligodeoxynucleotides (ODNs) using an automated DNA synthesizer. The hybridization ability of this boronated ODN to complementary RNA was clearly switched in the off-to-on direction upon $\mathrm{H}_{2} \mathrm{O}_{2}$ addition. Furthermore, we demonstrated $\mathrm{H}_{2} \mathrm{O}_{2}$-triggered gene silencing in mammalian cells using antisense oligonucleotides (ASOs) modified with $\mathrm{dT}^{\mathrm{B}}$. Our approach can be used for the regulation of any gene of interest by the sequence design of boronated ASOs and will contribute to the development of targeted disease therapeutics.
\end{abstract}

\section{Introduction}

Nucleic acids are fundamental molecules for biological processes as they are responsible for the storage, regulation, and expression of genetic information. Modulating the biological activities of nucleic acids is of value for therapeutic and diagnostic applications. Antisense oligonucleotides (ASOs) are among the most promising oligonucleotides for the downregulation of specific genes. ${ }^{1}$ ASOs hybridize with complementary mRNA to inhibit translation and reduce specific gene expression though the RNAse $\mathrm{H}$ degradation process or to modulate mRNA splicing pathways. Several antisense drugs have been approved by the US FDA in recent years. ${ }^{2-5}$ However, although ASOs are promising tools to control specific gene expression, a considerable drawback of the technology is the inability to regulate the activity of ASOs in a designated manner. If the activities of ASOs could be strictly controlled, as required for therapeutic use, their dosage could be reduced while maintaining their efficiency, and lesion specific knockdown of the target gene would be realized, reducing the off-target effect.

${ }^{a}$ Graduate School of Pharmaceutical Sciences, Osaka University, 1-6 Yamadaoka, Suita, Osaka 565-0871, Japan.E-mail: morihiro@bioorg.rcast.u-tokyo.ac.jp; obika@ phs.osaka-u.ac.jp

${ }^{b}$ National Institutes of Biomedical Innovation, Health and Nutrition (NIBIOHN), 7-6-8 Saito-Asagi, Ibaraki, Osaka 567-0085, Japan

$\dagger$ Electronic supplementary information (ESI) available: Full experimental details, ${ }^{1} \mathrm{H},{ }^{13} \mathrm{C}$ and ${ }^{31} \mathrm{P}$ spectra of all new compounds, HPLC charts, ESI-MS spectra of all new ODNs and representative UV melting data. See DOI: $10.1039 / \mathrm{c} 7 \mathrm{sc04318j}$

\$ Present address: Department of Chemistry and Biotechnology, Graduate School of Engineering, The University of Tokyo.
Photo-caging technology represents an effective means to the development of the spatial and temporal control of ASO activity. ${ }^{6-16}$ In particular, nucleobase-caged ASOs have been systematically investigated, thus facilitating the manipulation of biological phenomena by photo-irradiation. ${ }^{17-22}$ However, the use of other stimuli, such as small molecule-responsive caged ASOs, remain largely unexplored. ${ }^{23}$ The chemical environment in our body, as well as inside cells, differs in space and over time. The ability of caged nucleic acids to alter their properties under a specific biomarker in a lesion would provide new options for nucleic acid therapeutics.

Some diseased cells, such as inflamed cells ${ }^{24}$ and cancer cells, ${ }^{25}$ exhibit elevated intrinsic oxidative stress, and the amounts of reactive oxygen species (ROS) are increased. Thus, the development of molecular probes toward ROS is one of the best intriguing research fields. ${ }^{26}$ Hydrogen peroxide $\left(\mathrm{H}_{2} \mathrm{O}_{2}\right)$ is an ROS that exhibits good reactivity and is present in significant concentrations in vivo, and is thus an ideal candidate as a biomarker of tumours. Compared with normal cells, cancer cells have increased levels of $\mathrm{H}_{2} \mathrm{O}_{2}$ of up to $0.5 \mathrm{nmol} / 10^{4}$ cells per $h .{ }^{25}$ There is therefore great interest in developing ASOs that are activated by excess $\mathrm{H}_{2} \mathrm{O}_{2}$. We designed a series of boronated nucleosides $\left(\mathbf{d} \mathbf{T}^{\mathbf{B p i n}}, \mathbf{d} \mathbf{A}^{\mathbf{B p i n}}, \mathbf{d C}^{\mathbf{B p i n}}\right.$ and $\mathbf{d G}^{\mathbf{B p i n}}$ ) for the $\mathrm{H}_{2} \mathrm{O}_{2}$ triggered activation of ASOs (Fig. 1a). Arylboronic acids and their esters can effectively temporally mask their molecular activity. They are oxidized to phenol derivatives by $\mathrm{H}_{2} \mathrm{O}_{2}$ and subsequent 1,6-elimination releases the active molecule (Fig. 1b). Boronated small molecules have been used for the fluorescent detection of $\mathrm{H}_{2} \mathrm{O}_{2},{ }^{27}$ selective gene activation, ${ }^{28}$ and as cancer therapeutics. ${ }^{29-31}$ To adapt $\mathrm{H}_{2} \mathrm{O}_{2}$-responsive small 
a)<smiles>Cc1c[nH]c(=O)nc1OCc1ccc(B2OC(C)(C)C(C)(C)O2)cc1</smiles>
$\mathrm{dR}$ dT $T^{\text {Bpin }}$<smiles>Cn1ccc(NC(=O)OCc2ccc(OC(C)(C)C)cc2)nc1=O</smiles>
$d^{\text {Bpin }}$<smiles>CC1(C)OB(c2ccc(CC(=O)Nc3ncnc4[nH]cnc34)cc2)OC1(C)C</smiles>

dA $A^{\text {Bin }}$

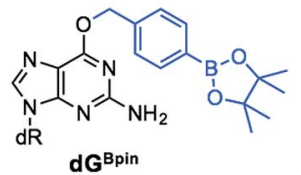

b)

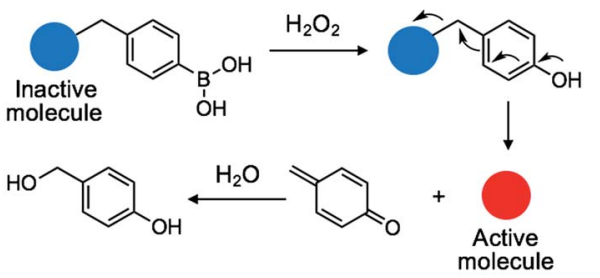

c) (S):OFF

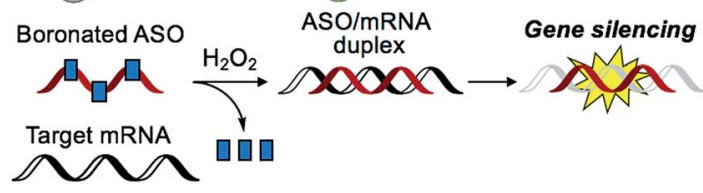

Fig. 1 (a) Chemical structure of boronated 2'-deoxyribonucleoside analogues synthesized in this study. (b) Schematic of $\mathrm{H}_{2} \mathrm{O}_{2}$-triggered molecule activation. (c) Gene silencing triggered by $\mathrm{H}_{2} \mathrm{O}_{2}$ through inactive boronated ASOs.

molecule technology to ASOs, we masked the Watson-Crick face of the nucleobase with pinacol borane. The sterically hindered arylboronate groups will interfere with duplex formation between the ASO and target mRNA. In the presence of $\mathrm{H}_{2} \mathrm{O}_{2}$, the boronate group will be swiftly removed, resulting in gene silencing through hybridization of the ASO to the target mRNA (Fig. 1c).

\section{Results and discussion}

\section{Synthesis of boronated nucleosides}

The synthesis of boronated nucleosides was started from suitably silylated sugars (Scheme 1). The $\mathrm{H}_{2} \mathrm{O}_{2}$ responsive pinacol borane moiety was introduced through a benzylic linker by $\mathrm{S}_{\mathrm{N}} \mathrm{Ar}$ reaction of a triazolyl nucleoside derivative ${ }^{32}$ for $\mathbf{d T}$ and by Mitsunobu reaction for dG. The removal of TIPDS by TBAF afforded boronated nucleoside $\mathbf{d T}^{\mathbf{B p i n}}(\mathbf{4})$ and $\mathbf{d G}^{\text {Bpin }}(\mathbf{6})$. In contrast, $\mathbf{d} \mathbf{A}^{\mathbf{B p i n}}$ and $\mathbf{d} \mathbf{C}^{\mathbf{B p i n}}$ have an arylboronate moiety linked via a carbamate spacer on their nucleobase. 4-(Hydroxymethyl) phenylboronic acid pinacol ester $\mathbf{1}$ was converted to the imidazole derivative in 2 steps. The imidazole was exposed to Meerwein reagent to prepare highly reactive imidazolium salt 2 in situ, then reacted with TIPDS-protected dC or dA. TBAF treatment caused degradation of the carbamate moiety, and therefore we used HF-pyridine or TASF for silyl deprotection to afford $\mathbf{d} \mathbf{A}^{\text {Bpin }}(\mathbf{8})$ and $\mathbf{d} \mathbf{C}^{\text {Bpin }}(\mathbf{1 0})$ (Scheme 1).

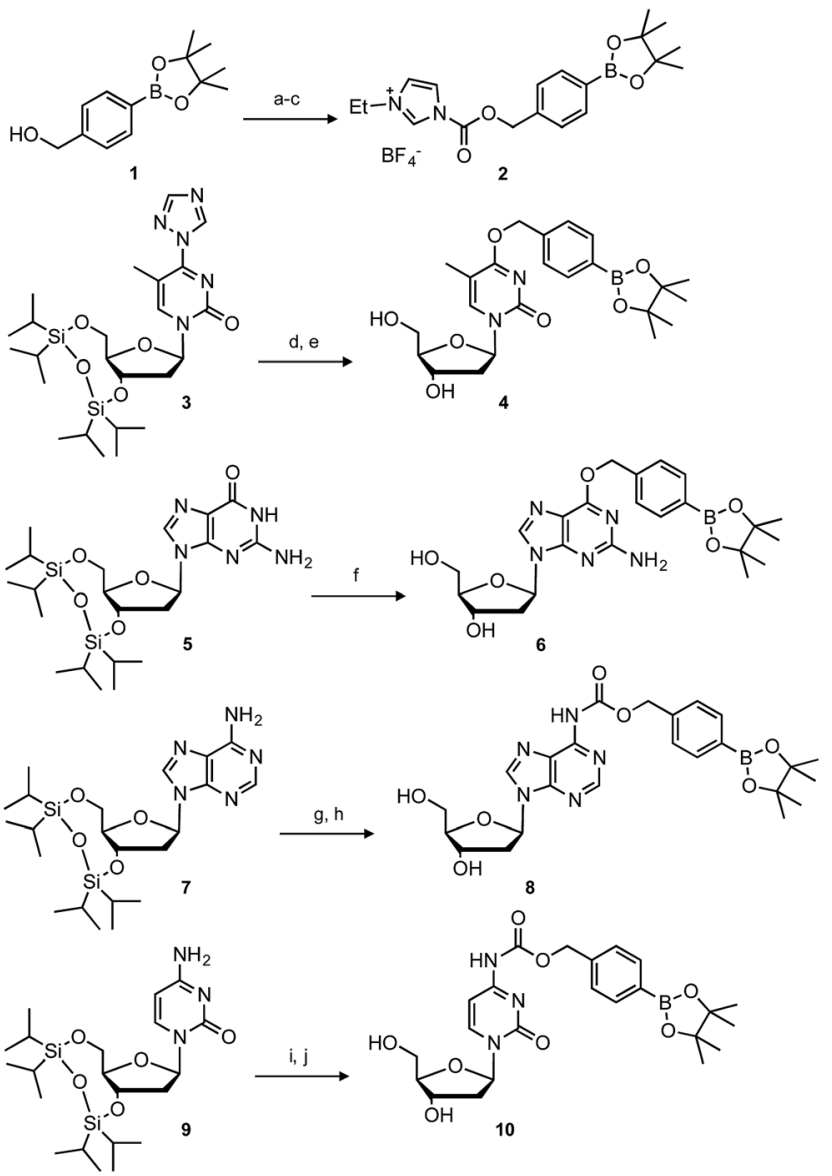

Scheme 1 Synthesis of boronated nucleoside analogues. Conditions: (a) triphosgene, $\mathrm{Na}_{2} \mathrm{CO}_{3}$, toluene, rt; (b) imidazole, toluene, rt, $87 \%$ over 2 steps; (c) $\mathrm{Et}_{3} \mathrm{OBF}_{4}, \mathrm{DCM}$, rt; (d) 1, DBU, MeCN, rt, 98\%; (e) TBAF, $\mathrm{THF}, 0{ }^{\circ} \mathrm{C}, 72 \%$; (f) 1, DIAD, $\mathrm{PPh}_{3}, 1,4$-dioxane, rt, then TBAF, $10 \%$; (g) 2 , DCM, $0{ }^{\circ} \mathrm{C}$ to rt, $91 \%$; (h) TASF, DMF, $0{ }^{\circ} \mathrm{C}, 62 \%$; (i) $2, \mathrm{DCM}, 0{ }^{\circ} \mathrm{C}$ to rt, 92\%; (j) HF-pyridine, $60{ }^{\circ} \mathrm{C}, 52 \%$.

\section{$\mathrm{H}_{2} \mathrm{O}_{2}$-decaging of boronated nucleosides}

With the caged nucleoside monomers in hand, we determined their conversion yields to the corresponding natural nucleosides by $\mathrm{H}_{2} \mathrm{O}_{2}$ treatment using HPLC analysis. Exposed to the equimolar equivalent of $\mathrm{H}_{2} \mathrm{O}_{2}$ in sodium phosphate buffer ( $\mathrm{pH}$ $=7.2$ ), virtually all of $\mathbf{d T}^{\mathrm{Bpin}}$ was converted to thymidine within $20 \mathrm{~min}$ (96\% yield, Fig. 2a). Other boronated nucleosides were also promptly converted to the corresponding nucleosides in 67-88\% yields (Fig. $2 \mathrm{~b}$ and ESI $\dagger$ ). The lower yield of $\mathbf{d G}^{\text {Bpin }}$ was due to the generation of a side product, possibly the 8-oxo-dG analogue. ${ }^{33,34}$ Of the synthesized nucleoside analogues, $\mathbf{d T}^{\mathrm{Bpin}}$ showed the best reaction yield and kinetics for $\mathrm{H}_{2} \mathrm{O}_{2}$-decaging. To provide further insights into the decaging mechanism, we examined the inducible reactivity of $\mathbf{d T}^{\mathbf{B p i n}}$ toward other ROS, such as tert-butyl-hydroperoxide (TBHP), hypochlorite $\left(\mathrm{ClO}^{-}\right)$, hydroxyl radical, tert-buthoxy radical, superoxide $\left(\mathrm{O}_{2}{ }^{-}\right)$, and nitric oxide. We found that the decaging reaction of $\mathbf{d T}^{\mathbf{B p i n}}$ was highly selective for $\mathrm{H}_{2} \mathrm{O}_{2}$ over the other ROS (Fig. 2c). The selective reaction of $\mathbf{d T}^{\mathbf{B p i n}}$ with $\mathrm{H}_{2} \mathrm{O}_{2}$ is consistent with the observations of other groups. ${ }^{28-31}$ We also checked the reactivity 
a)

a)

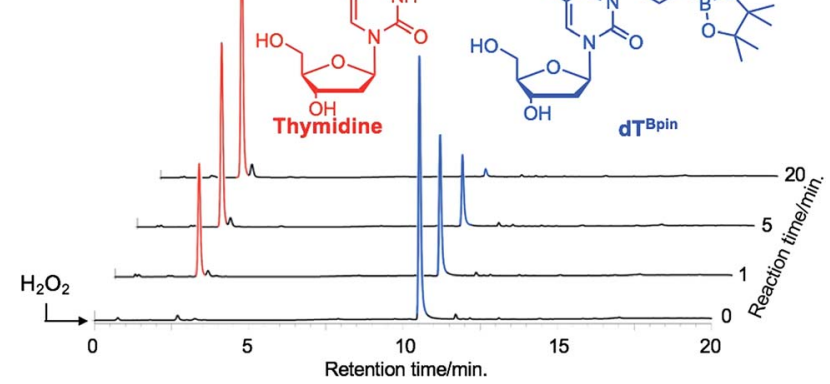

b)

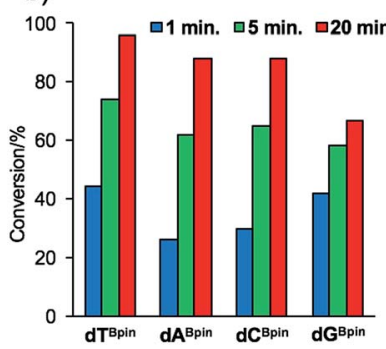

c)

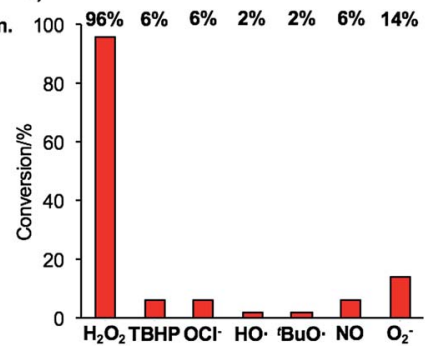

Fig. 2 (a) HPLC chromatograms of $d T^{\text {Bpin }}$ after $\mathrm{H}_{2} \mathrm{O}_{2}$ addition at different time points. (b) Conversion rate of each boronated nucleoside analogue to the corresponding natural nucleoside. (c) $\mathrm{H}_{2} \mathrm{O}_{2}-$ selectivity of $d T^{\text {Bpin }}$ toward other ROS.

of $\mathbf{d T}^{\mathbf{B p i n}}$ toward peroxynitrite ( $\mathrm{ONOO}^{-}$), which is reported to be a potential oxidant of arylboronic acid moieties. ${ }^{35}$ However, in the same reaction conditions, almost no conversion to thymidine was observed (see HPLC chromatograms in ESI $\dagger$ ). The halflife of $\mathrm{ONOO}^{-}$in neutral buffer is extremely short ${ }^{36}$ and an equimolar equivalent of $\mathrm{ONOO}^{-}$may not be sufficient for $\mathbf{d T}^{\text {Bpin }}$ decaging.

\section{Boronated ODN synthesis}

Although the introduction of arylboronate groups into oligodeoxynucleotides (ODNs) is very interesting due to their characteristic function,,$^{37,38}$ the direct incorporation of arylboronic acid moieties using solid phase synthesis is challenging because of their hygroscopicity. Wang and co-workers reported the synthesis of arylboronic acid-modified ODNs using a postsynthetic approach. ${ }^{38}$ However, this strategy limits the design of boronated ODNs. We predicted that phosphoramidites modified with pinacol borane would be less hygroscopic and could be applied to direct DNA synthesis.

We incorporated $\mathbf{d T}^{\mathbf{B p i n}}$ into ODN to take into account both the decaging efficiency and stability of the ODN under DNA synthesis conditions. Fortunately, phosphoramidite 11, prepared from $\mathbf{d T}^{\mathbf{B p i n}}$ nucleoside $\mathbf{4}$ (see ESI $\dagger$ for the synthesis), could be incorporated into the ODN using standard solid phase synthesis procedures. After cleavage from the solid support with ammonium hydroxide, the protecting groups were removed by exposure to $50 \mathrm{mM} \mathrm{K}_{2} \mathrm{CO}_{3}$ in methanol (Fig. 3a). Subsequent HPLC purification afforded highly pure ODN14 in which the pinacol ester group of $\mathbf{d T}^{\text {Bpin }}$ was hydrolysed (see MALDI-TOF and ESI MS analysis in ESI $\dagger$ ). ODN14 was observed as the dehydrated form on ESI MS that corresponds to Wang's report. ${ }^{38}$ To the best of our knowledge, this is the first example of the incorporation of the arylboronic acid group into an ODN without the need to use a post-synthetic approach.

\section{$\mathrm{H}_{2} \mathrm{O}_{2}$-activation of boronated ODN}

Next, we analysed the $\mathrm{H}_{2} \mathrm{O}_{2}$ reactivity of $\mathbf{d T}^{\mathbf{B}}$-modified ODN14 by HPLC (Fig. 3b). When ODN14 was exposed to an excess amount of $\mathrm{H}_{2} \mathrm{O}_{2}$ at rt, the ODN14 peak at 8.8 min completely disappeared and another peak appeared within $30 \mathrm{~min}$ in the HPLC profile. The resulting ODN, with a retention time of $2.0 \mathrm{~min}$, was shown by MALDI-TOF MS spectrometry to be ODN14 in which the boronic acid moiety of $\mathbf{d T}^{\mathbf{B}}$ was absent (see MALDI-TOF MS analysis in SI). The oxidation of $\mathbf{d} \mathbf{T}^{\mathbf{B}}$ by $\mathrm{H}_{2} \mathrm{O}_{2}$ remained clean and rapid.

The duplex-forming ability of ODN14 toward its complementary RNA (cRNA) strand was measured in the presence and absence of $\mathrm{H}_{2} \mathrm{O}_{2}$. Under the $\mathrm{H}_{2} \mathrm{O}_{2}$-free condition, the modified duplex ODN14:cRNA (Fig. 3c: blue line) was significantly destabilized compared with the unmodified ODN15:cRNA duplex (Fig. 3c: green line) $\left(\Delta T_{\mathrm{m}}=14{ }^{\circ} \mathrm{C}\right)$. The stabilities of the base pairs formed between $\mathbf{T}^{\text {Bpin }}$ and other nucleobases (G, U, and C) were also lower than the T:A base pair (Table S1 $\dagger$ ). These results indicate that the boronic acid moiety effectively inhibits complementary base pairing, probably due to steric hindrance. The $T_{\mathrm{m}}$ of ODN14:cRNA in the presence of $\mathrm{H}_{2} \mathrm{O}_{2}$ (Fig. 3c: red line) was comparable to that of ODN15: $\operatorname{cRNA}\left(\Delta T_{\mathrm{m}}=1{ }^{\circ} \mathrm{C}\right)$. The mismatch discrimination ability of ODN14 was not decreased by $\mathrm{H}_{2} \mathrm{O}_{2}$ addition (Table $\mathrm{S} 1 \dagger$ ). These excellent hybridization properties of ODN14 were also seen toward complementary

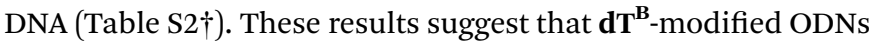
enable switching of their hybridization to complementary strand in the off-to-on direction upon $\mathrm{H}_{2} \mathrm{O}_{2}$ treatment.

\section{$\mathrm{H}_{2} \mathrm{O}_{2}$-triggered gene silencing in mammalian cells}

The $T_{\mathrm{m}}$ results prompted us to use the $\mathrm{H}_{2} \mathrm{O}_{2}$-responsive caged ODNs in biological systems. We incorporated $\mathbf{d T}^{\mathbf{B}}$ into the gap region of ASO targeting Mus Scarb1 mRNA (Fig. 4a). Scarb1 has been implicated in several tumours, ${ }^{39}$ and targeted ASOs may provide a novel cancer therapeutic approach. $\mathbf{S}_{\mathbf{0}}$ includes phosphorothioate and locked nucleic acid (LNA) modifications to increase nuclease resistance and affinity toward the target mRNA, respectively. To determine the effect of boronate caging groups on antisense potency, we synthesized a set of three ASOs $\mathbf{S}_{\mathbf{1}}-\mathbf{S}_{\mathbf{3}}$ containing 1-3 $\mathbf{d T}^{\mathbf{B}}$ units. Hepa-1c1c7 cells, a line derived from mice hepatoma, were treated with the ASOs by simple addition to the medium with $\mathrm{CaCl}_{2}$ (ref. 40) and incubated for $48 \mathrm{~h}$ in the absence or presence of $\mathrm{H}_{2} \mathrm{O}_{2}(10 \mu \mathrm{M})$. Scarb1 mRNA levels were then quantified using qRT-PCR (Fig. 4b). Under the $\mathrm{H}_{2} \mathrm{O}_{2}$ free condition, the knockdown efficiency of target mRNA by $\mathbf{S}_{\mathbf{1}}$ was almost the same as that by $\mathbf{S}_{\mathbf{0}}$ (positive control). On the other hand, $\mathbf{S}_{\mathbf{2}}$ and $\mathbf{S}_{\mathbf{3}}$ showed low antisense efficiency, similar to $\mathbf{S}_{\mathbf{A}}$ (negative control). This result indicates that at least two $\mathbf{d T}^{\mathbf{B}}$ units are necessary to mask the gene silencing potency of the ASO. In contrast, when exposed to $10 \mu \mathrm{M} \mathrm{H}_{2} \mathrm{O}_{2}$, the antisense efficiencies of $\mathbf{S}_{\mathbf{2}}$ and $\mathbf{S}_{\mathbf{3}}$ are comparable to that of $\mathbf{S}_{\mathbf{0}}$. The 
a)

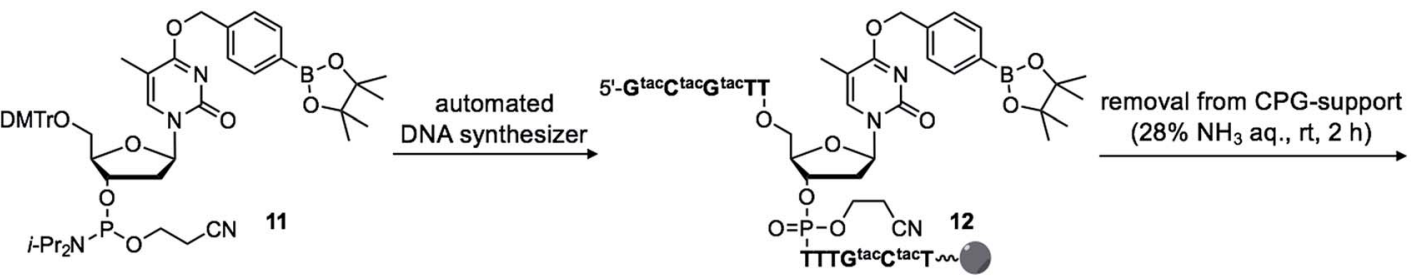

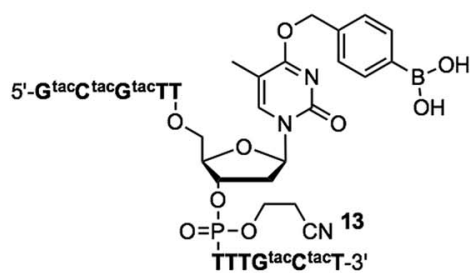

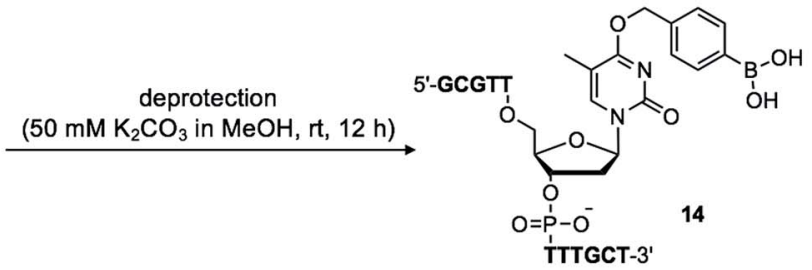

b)

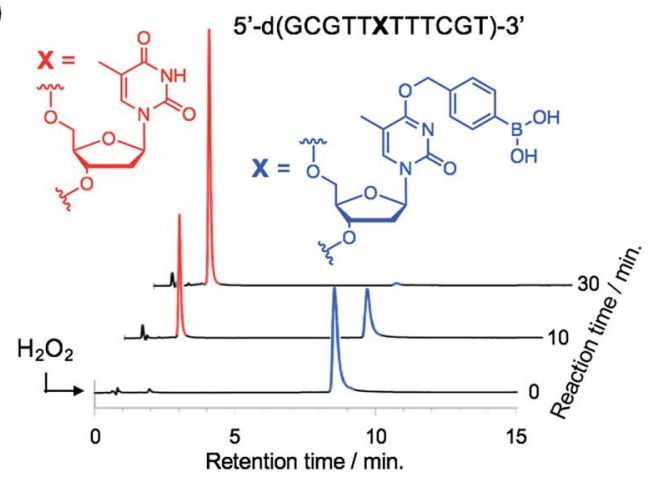

c)

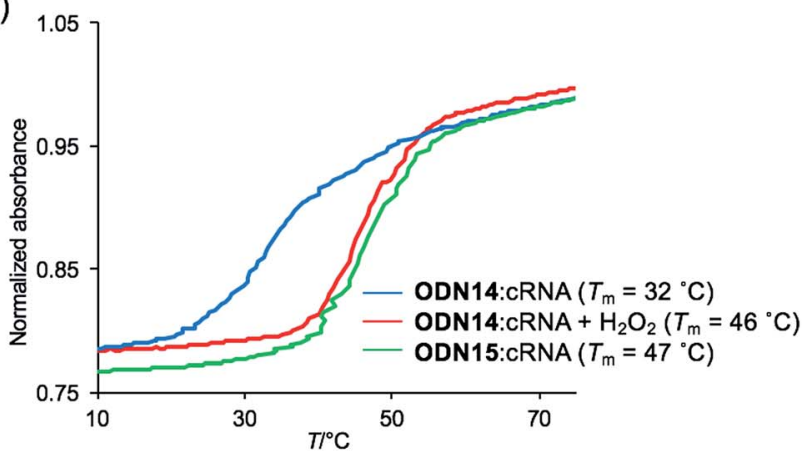

Fig. 3 (a) Synthetic scheme of boronated ODN. tac = tert-butylphenoxyacetyl. (b) HPLC chromatograms of ODN14 after $\mathrm{H}_{2} \mathrm{O}_{2}$ addition at different time points. (c) Thermal melting curves of the duplex formed between ODN14 and complementary RNA in the presence or absence of $\mathrm{H}_{2} \mathrm{O}_{2}$.

negligible change in gene silencing upon $\mathrm{H}_{2} \mathrm{O}_{2}$ treatment without ASO indicates that $10 \mu \mathrm{M} \mathrm{H}_{2} \mathrm{O}_{2}$ does not affect the expression level of Mus Scarb1 mRNA. However, $\mathbf{S}_{\mathbf{A}}$ showed

a)

\begin{tabular}{|c|c|}
\hline ASO & Sequence $\left(5^{\prime}-3^{\prime}\right)$ \\
\hline$S_{0}$ & $\mathrm{TC}^{\mathrm{m}}$ agtcatgactTC $\mathrm{m}$ \\
\hline $\mathrm{s}_{1}$ & $\mathrm{TC}^{\mathrm{m}}$ agt $^{\mathrm{B}}$ catgactTC $\mathrm{m}$ \\
\hline$s_{2}$ & $T{ }^{m}$ agt ${ }^{B}{ } a^{\mathrm{B}}{ }^{\text {gact }} T \mathrm{C}^{\mathrm{m}}$ \\
\hline $\mathbf{s}_{3}$ & $\mathrm{TC}^{\mathrm{m}}$ agt $^{\mathrm{B}} \mathrm{cat}^{\mathrm{B}}{ }_{\text {act }} \mathrm{B}^{\mathrm{B}} \mathrm{C}^{\mathrm{m}}$ \\
\hline $\mathbf{s}_{\mathrm{A}}$ & $\mathrm{GC}^{\mathrm{m}}$ attggtatTC $\mathrm{m} A$ \\
\hline
\end{tabular}

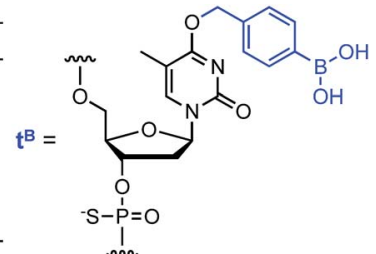

b)

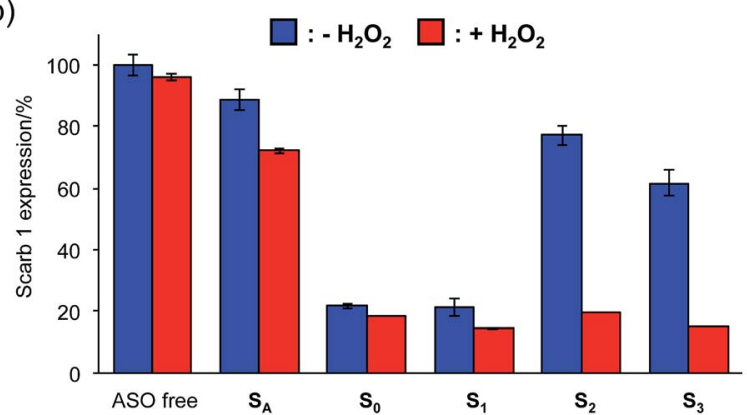

Fig. 4 (a) Sequences of ASOs. $n=$ DNA, $N=$ LNA $\left(C^{m}=\right.$ LNA-5-Mecytidine), all internucleosidic linkages are phosphorothioated. (b) Intercellular gene silencing triggered by $\mathrm{H}_{2} \mathrm{O}_{2}$ using boronate ASOs. Three independent experiments were averaged and the error bars represent standard deviation. about $15 \%$ lower mRNA expression after $\mathrm{H}_{2} \mathrm{O}_{2}$ treatment, suggesting the combination of the modified oligonucleotide and $\mathrm{H}_{2} \mathrm{O}_{2}$ may affect the Scarb1 mRNA expression level. Targeting other mRNAs or applying other chemical modifications could help to obtain further insights for this phenomenon. Taken together, these results clearly demonstrate that the ASOs $\mathbf{S}_{\mathbf{2}}$ and $\mathbf{S}_{3}$ enable excellent off-to-on switching of gene silencing in mammalian cells triggered by $\mathrm{H}_{2} \mathrm{O}_{2}$.

\section{Conclusions}

We designed and synthesized arylboronate-modified nucleosides which are promptly decaged and converted to natural nucleosides by $\mathrm{H}_{2} \mathrm{O}_{2}$. The boronated thymidine $\mathbf{d T}^{\text {Bpin }}$ phophoramidite could be directly used in automated DNA synthesis and a $\mathbf{T}^{\mathbf{B}}$ :A base pair in the duplex could be employed as a temporary mismatch until $\mathrm{H}_{2} \mathrm{O}_{2}$ addition. Moreover, $\mathbf{d T}^{\mathbf{B}}$ modified ASOs were demonstrated to be $\mathrm{H}_{2} \mathrm{O}_{2}$ switches that can control target mRNA expression. $\mathrm{H}_{2} \mathrm{O}_{2}$ is known to be involved in various diseases such as cancer, neurodegeneration, ${ }^{41}$ and diabetes. ${ }^{42}$ Our results indicate that boronated ASOs are promising tools to control target gene expression in a designated manner and as a prodrug-type nucleic acid therapeutic for selective disease treatment. Furthermore, the design of boronated nucleotides can be easily adapted to other nucleic acid 
agents such as aptamers, triplex-forming oligonucleotides (TFOs), and small interfering RNAs (siRNAs).

\section{Experimental}

General

Reagents and solvents were purchased from commercial suppliers and used without purification unless otherwise specified. All experiments involving air and/or moisture sensitive compounds were carried out under an Ar atmosphere. All reactions were monitored with analytical TLC (Merck Kieselgel 60 F254; Merck, Darmstadt, Germany). Flash column chromatography was carried out using EPCLC-W-Prep 2XY (YAMAZEN, Osaka, Japan). Physical data were measured as follows. NMR spectra were recorded on a JNM-ECS-400 spectrometer (JEOL, Tokyo, Japan) using $\mathrm{CDCl}_{3}$ or DMSO- $d_{6}$ as the solvent with tetramethylsilane as an internal standard. IR spectra were recorded on a FT/IR-4200 spectrophotometer (JASCO, Tokyo, Japan). Optical rotations were recorded on a JASCO P-2200 instrument. FAB mass spectra were measured using a JEOL JIM-700 mass spectrometer. Solid-phase ODN synthesis was performed using an nS-8 II oligonucleotide synthesizer (GeneDesign, Osaka, Japan). MALDI-TOF mass spectra were recorded on an ultrafleXtreme mass spectrometer (Bruker Daltonics, Billerica, MA, USA). ESI mass spectra were recorded on a Xevo G2-XS QTof (Waters, Milford, MA, USA). UV/vis absorption measurements and UV melting experiments were performed using a UV1650PC UV-vis spectrophotometer equipped with a TMSPC-8 $T_{\mathrm{m}}$ analysis accessory (SHIMADZU, Kyoto, Japan).

\section{$\mathrm{H}_{2} \mathrm{O}_{2}$-decaging of boronated nucleosides}

A reaction solution of boronated nucleoside $(1 \mathrm{mM})$ and $\mathrm{H}_{2} \mathrm{O}_{2}(1$ $\mathrm{mM}$ ) in a DMSO-containing buffer (10 $\mathrm{mM}$ potassium phosphate, $\mathrm{pH}$ 7.2, $100 \mathrm{mM} \mathrm{NaCl}$, and DMSO 5\% v/v) was incubated at room temperature for the prescribed times and immediately subjected to reversed-phase HPLC analysis using MeCN in $0.1 \mathrm{M}$ triethylammonium acetate buffer ( $\mathrm{pH}$ 7.0). The conversion rate of boronated nucleoside was determined from the corresponding peak area monitored at $260 \mathrm{~nm}$.

\section{Other ROS-decaging of $\mathbf{d T}^{\mathrm{Bpin}}$}

A reaction solution of boronated nucleoside $(1 \mathrm{mM})$ and reactive oxygen species $(1 \mathrm{mM})$ in a DMSO-containing buffer $(10 \mathrm{mM}$ potassium phosphate, $\mathrm{pH} 7.2,100 \mathrm{mM} \mathrm{NaCl}$, and DMSO 5\% v/v) was incubated at room temperature for $12 \mathrm{~h}$ and immediately subjected to reversed-phase HPLC analysis using MeCN in $0.1 \mathrm{M}$ triethylammonium acetate buffer $\left(\mathrm{pH}\right.$ 7.0). $\mathrm{H}_{2} \mathrm{O}_{2}$, tertbutylhydroperoxide (TBHP), and hypochlorite $(\mathrm{NaOCl})$ were delivered from $30 \%, 70 \%$, and $10 \%$ aqueous solutions respectively. Hydroxyl radical ( $\left.\mathrm{HO}^{\circ}\right)$ and tert-butoxy radical $\left({ }^{t} \mathrm{BuO}^{\circ}\right)$ were generated by the reaction of $5 \mathrm{mM}\left(\mathrm{NH}_{4}\right)_{2} \mathrm{Fe}\left(\mathrm{SO}_{4}\right)_{2}, 10 \mathrm{mM}$ EDTA with $1 \mathrm{mM} \mathrm{H}_{2} \mathrm{O}_{2}$ or TBHP, respectively. Nitric oxide (NO) was generated from PROLI NONOate. Superoxide $\left(\mathrm{O}_{2}{ }^{-}\right)$was produced by xanthine oxidase $\left(4.5 \times 10^{-3} \mathrm{mg} / 100 \mu \mathrm{L}\right)$ in the presence of hypoxanthine $(2 \mathrm{mM})$ and catalase $\left(0.4 \mathrm{mg} \mathrm{mL}^{-1}\right)$. Peroxynitrite $\left(\mathrm{ONOO}^{-}\right)$was delivered from $\mathrm{NaOH}$ aqueous solution and the concentration of $\mathrm{ONOO}^{-}$was determined using the absorption at $300 \mathrm{~nm}\left(\varepsilon=1670 \mathrm{M}^{-1} \mathrm{~cm}^{-1}\right)$. The solution was diluted with phosphate buffer and used immediately. The conversion rate of boronated nucleoside was determined from the corresponding peak area monitored at $260 \mathrm{~nm}$.

\section{ODN synthesis}

Solid-phase ODN synthesis was performed using commercially available reagents and phosphoramidites. $\mathbf{d T}^{\mathbf{B p i n}}$ phosphoramidite was chemically synthesized as described (Scheme S1 $\dagger$ ). ODNs were synthesized (with trityl-on) on a $500 \AA$ CPG solid support column ( $1 \mu \mathrm{mol}$ scale) using 5-ethylthio- $1 H$-tetrazole $(0.25 \mathrm{M}$ in $\mathrm{MeCN})$ as the activator and $0.05 \mathrm{M}$ ((dimethylaminomethylidene)amino)-3H-1,2,4-dithiazaoline-3-thione (DDTT) in pyridine/MeCN $(1: 1, \mathrm{v} / \mathrm{v})$ for thiolation. The standard synthesis cycle was used for assembly of the reagents and synthesis of the oligonucleotides, except that the coupling time was extended to $5 \mathrm{~min}$ for LNA monomers. Cleavage from the solid support and deprotection were accomplished with $28 \% \mathrm{w} /$ w $\mathrm{NH}_{4} \mathrm{OH}$ aqueous solution at room temperature for $2 \mathrm{~h}$ and potassium carbonate $(0.05 \mathrm{M}$ in methanol solution) at room temperature for $12 \mathrm{~h}$, respectively. The crude ODNs were purified on a Sep Pack column (Waters) followed by RP-HPLC on an XBridge $^{\mathrm{TM}}$ OST C18 column, $2.5 \mu \mathrm{m}, 10 \times 50 \mathrm{~mm}$ (Waters) using MeCN in 0.1 M triethylammonium acetate buffer ( $\mathrm{pH} 7.2$ ). The purified ODNs were quantified by UV absorbance at $260 \mathrm{~nm}$ and confirmed by MALDI-TOF or ESI mass spectrometry. In ESI MS measurement, boronated ODN and ASO were detected as the dehydrated form, which is consistent with the observation of Wang's group. ${ }^{38}$

\section{$\mathrm{H}_{2} \mathrm{O}_{2}$-decaging of boronated ODN}

A reaction solution of ODN14 $(4 \mu \mathrm{M})$ and $\mathrm{H}_{2} \mathrm{O}_{2}(1 \mathrm{mM})$ in a buffer (10 mM potassium phosphate, $\mathrm{pH} 7.2,100 \mathrm{mM} \mathrm{NaCl})$ was incubated at room temperature for the prescribed times and immediately subjected to reversed-phase HPLC analysis using MeCN in 0.1 M triethylammonium acetate buffer ( $\mathrm{pH}$ 7.0).

\section{UV melting experiments}

Melting temperatures $\left(T_{\mathrm{m}}\right)$ were determined by measuring the change in absorbance at $260 \mathrm{~nm}$ as a function of temperature using a SHIMADZU UV-vis UV-1650PC spectrophotometer equipped with a TMSPC-8 $T_{\mathrm{m}}$ analysis accessory. The melting samples were denatured at $100{ }^{\circ} \mathrm{C}$ and annealed slowly to room temperature. Absorbance was recorded in the forward and reverse direction at temperatures between 5 to $90{ }^{\circ} \mathrm{C}$ at a rate of $0.5^{\circ} \mathrm{C} \min ^{-1}$.

\section{Cell culture}

Hepa-1c1c7 cells were obtained from the European Collection of Authenticated Cell Cultures (ECACC; Salisbury, UK). The cell line was maintained at $37{ }^{\circ} \mathrm{C}$ and $5 \% \mathrm{CO}_{2}$ in Dulbecco's Modified Eagle's Medium (DMEM; Nacalai Tesque, Kyoto, Japan) supplemented with $10 \%$ heat-inactivated foetal bovine serum (FBS) and antibiotics. 
Evaluation of the in vitro activity of $\mathrm{dT}^{\mathrm{B}}$-modified ASOs in the absence or presence of $\mathrm{H}_{2} \mathrm{O}_{2}$

Hepa-1c1c7 cells were seeded at $5.0 \times 10^{3}$ cells per well in 96well plates (Corning, New York, NY, US) containing 10\% FBS/ DMEM. After 24 h, $100 \mathrm{nM}$ ASO was added and the cells were cultured in medium supplemented with $9 \mathrm{mM} \mathrm{CaCl}_{2}$ in the absence or presence of $\mathrm{H}_{2} \mathrm{O}_{2}(10 \mu \mathrm{M})$. After $48 \mathrm{~h}$, total RNA was isolated using a QIAGEN RNeasy kit (QIAGEN, Valencia, CA, USA). Reduction of target mRNA expression was determined by real time qRT-PCR using a One Step SYBR PrimeScript PLUS RTPCR kit (Takara Bio Inc., Kusatsu, Japan) and analysed with a StepOnePlus system (Applied Biosystems; Foster City, CA, USA). The primers used in this study were specific for the mouse Scarb1 gene (forward: 5'-TGACAACGACACCGTGTCCT-3'; reverse: $5^{\prime}$-ATGCGACTTGTCAGGCTGG-3') and for the mouse GAPDH gene (forward: $5^{\prime}$-TGCACCACCAACTGCTTAG- $3^{\prime}$; reverse: $5^{\prime}$-GATGCAGGGATGATGTTC- $\left.3^{\prime}\right)$. The level of target (Scarb1) gene expression was normalized to that of $G A P D H$ in the absence of $\mathrm{H}_{2} \mathrm{O}_{2}$.

\section{Conflicts of interest}

There are no conflicts to declare.

\section{Acknowledgements}

This work was supported by KAKENHI from the Japan Society for the Promotion of Science (JSPS) and the Platform Project for Supporting Drug Discovery and Life Science Research from the Japan Agency for Medical Research and Development (AMED). S. M. is grateful for a Research Fellowship for Young Scientists from JSPS.

\section{Notes and references}

1 T. Yamamoto, M. Nakatani, K. Narukawa and S. Obika, Future Med. Chem., 2011, 3, 339-365.

2 C. M. Perry and J. A. Balfour, Drugs, 1999, 57, 375-380.

3 R. S. Geary, B. F. Baker and S. T. Crooke, Clin. Pharmacokinet., 2015, 54, 133-146.

4 K. R. Q. Lim, R. Maruyama and T. Yokota, Drug Des., Dev. Ther., 2017, 11, 533-545.

5 E. W. Ottesen, Transl. Neurosci., 2017, 8, 1-6.

6 I. A. Shestopalov, S. Sinha and J. K. Chen, Nat. Chem. Biol., 2007, 3, 650-651.

7 X. Ouyang, I. A. Shestopalov, S. Sinha, G. Zheng, C. L. W. Pitt, W. Li, A. J. Olson and J. K. Chen, J. Am. Chem. Soc., 2009, 131, 13255-13269.

8 X. Tang, M. Su, L. Yu, C. Lv, J. Wang and Z. Li, Nucleic Acids Res., 2010, 38, 3848-3855.

9 G. Zheng, L. Cochella, J. Liu, O. Hobert and W. Li, ACS Chem. Biol., 2011, 6, 1332-1338.

10 S. Yamazoe, I. A. Shestopalov, E. Provost, S. D. Leach and J. K. Chen, Angew. Chem., Int. Ed., 2012, 51, 6908-6911.

11 A. Tallafuss, D. Gibson, P. Morcos, Y. Li, S. Seredick, J. Eisen and P. Washbourne, Development, 2012, 139, 1691-1699.
12 J. C. Griepenburg, B. K. Ruble and I. J. Dmochowski, Bioorg. Med. Chem., 2013, 21, 6198-6204.

13 L. Wu, Y. Wang, J. Wu, C. Lv, J. Wang and X. Tang, Nucleic Acids Res., 2013, 41, 677-686.

14 S. Yamazoe, Q. Liu, L. E. McQuade, A. Deiters and J. K. Chen, Angew. Chem., Int. Ed., 2014, 53, 10114-10118.

15 J. C. Griepenburg, T. L. Rapp, P. J. Carroll, J. Eberwine and I. J. Dmochowski, Bioorg. Med. Chem., 2013, 21, 6198-6204.

16 A. Y. Payumo, L. E. McQuade, W. J. Walker, S. Yamazoe and J. K. Chen, Nat. Chem. Biol., 2016, 12, 694-701.

17 D. D. Young, H. Lusic, M. O. Lively, J. A. Yoder and A. Deiters, ChemBioChem, 2008, 9, 2937-2940.

18 A. Deiters, R. A. Garner, H. Lusic, J. M. Govan, M. Dush, N. M. Nascone-Yoder and J. A. Yoder, J. Am. Chem. Soc., 2010, 132, 15644-15650.

19 C. M. Connelly, R. Uprety, J. Hemphill and A. Deiters, Mol. BioSyst., 2012, 8, 2987-2993.

20 J. M. Govan, R. Uperty, M. Thomas, H. Lusic, M. O. Lively and A. Deiters, ACS Chem. Biol., 2013, 8, 2272-2282.

21 F. Schäfer, J. Wagner, A. Knau, S. Dimmeler and A. Heckel, Angew. Chem., Int. Ed., 2013, 52, 13558-13561.

22 J. Hemphill, Q. Liu, R. Uprety, S. Samanta, M. Tsang, R. L. Juliano and A. Deiters, J. Am. Chem. Soc., 2015, 137, 3656-3662.

23 M. Ikeda and M. Kabumoto, Chem. Lett., 2017, 46, 634-640.

24 L. Rong, C. Zhang, Q. Lei, M. M. Hu, J. Feng, H. B. Shu, Y. Liu and X. Z. Zhang, Regener. Biomater., 2016, 3, 217-222.

25 T. P. Szatrowski and C. F. Nathan, Cancer Res., 1991, 51, 794798.

26 X. Chen, F. Wang, J. Y. Hyun, T. Wei, J. Qiang, X. Ren, I. Shin and J. Yoon, Chem. Soc. Rev., 2016, 45, 2976-3016.

27 A. R. Lippert, G. C. Van De Bittner and C. J. Chang, Acc. Chem. Res., 2011, 44, 793-804.

28 J. M. Govan, A. L. Mclver, C. Riggsbee and A. Deiters, Angew. Chem., Int. Ed., 2012, 51, 9066-9070.

29 Y. Kuang, K. Balakrishnan, V. Gandhi and X. Peng, J. Am. Chem. Soc., 2011, 133, 19278-19281.

30 E. J. Kim, S. Bhuniya, H. Lee, H. M. Kim, C. Cheong, S. Maiti, K. S. Hong and J. S. Kim, J. Am. Chem. Soc., 2014, 136, 1388813894.

31 H. W. Liu, X. X. Hu, K. L. Y. Liu, Q. Rong, L. Zhu, L. Yuan, F. L. Qu, X. B. Zhang and W. Tan, Chem. Sci., 2017, 8, 7689-7695.

32 V. Vendrell-Criado, G. M. Rodriguez-Muñiz, M. C. Cuquerella, V. Lhiaubet-Vallet and M. A. Miranda, Angew. Chem., Int. Ed., 2013, 52, 6476-6479.

33 P. Zhao, L. Zhou, Z. Nie, X. Xu, W. Li, Y. Huang, K. He and S. Yao, Anal. Chem., 2013, 85, 6279-6286.

34 T. Sekiguchi, R. Ito, H. Hayakawa and M. Sekiguchi, J. Biol. Chem., 2013, 288, 8128-8135.

35 J. Zielonka, A. Sikora, M. Hardy, J. Joseph, B. P. Dranka and B. Kalyanaraman, Chem. Res. Toxicol., 2012, 25, 1793-1799.

36 R. Radi, J. Biol. Chem., 2013, 37, 26464-26472.

37 A. E. Hargrove, A. D. Ellington, E. V. Anslyn and J. L. Sessler, Bioconjugate Chem., 2011, 22, 388-396.

38 C. Dai, L. Wang, J. Sheng, H. Peng, A. B. Draganov, Z. Huang and B. Wang, Chem. Commun., 2011, 47, 3598-3600. 
39 A. Lacko, M. Nair, S. Paranjape, S. Johnson and W. McConathy, Anticancer Res., 2002, 22, 2045-2049.

40 S. Hori, T. Yamamoto, R. Waki, F. Wada, M. Noda and S. Obika, Nucleic Acids Res., 2015, 43, e128.
41 S. DiMauro and E. A. Schon, Annu. Rev. Neurosci., 2008, 31, 91-123.

42 R. Pop-Busui, A. Sima and M. Stevens, Diabetes/Metab. Res. Rev., 2006, 22, 257-273. 